\title{
GAMBARAN PERSEPSI PASIEN TERHADAP PELAKSANAAN PERILAKU CARING DALAM PELAYANAN KEPERAWATAN DI RUANGAN RAWAT INAP BEDAH RSUD SOLOK
}

\author{
NETTY HERAWATI \\ Akademi Keperawatan YPTK Solok
}

\begin{abstract}
Abstrak: The quality of health services and the image of a hospital is largely determined by the role of nurses, because $90 \%$ of health services in hospitals are provided by nurses. in providing quality nursing services can be applied by using caring behavior in providing nursing care to clients. Caring is special and depends on the relationship between the nurse and the client, where caring facilitates the nurse's ability to recognize the client so the nurse can find out the client's problem and find and implement a solution. The survey conducted by researchers at Solok District Hospital on evaluating the quality of nursing services to patient satisfaction in the inpatient office of Solok Hospital obtained a surgical room with $42 \%$ good, and $58 \%$ less good. The fact that was found in the field more than half (59.4\%) of respondents had a negative perception of the implementation of nurses caring behavior in the operating room in Solok Hospital and more than half (40.6\%) of respondents had a positive perception of the implementation of nurses caring behavior in the room inpatient surgery. It is expected that all nurses, especially nurses in the room can carry out caring behaviors to all patients optimally because caring behavior by nurses can optimally affect how a person or patient thinks, feels and behaves in dealing with others, so as to provide patient satisfaction towards nursing services
\end{abstract}

Keywords: patient perception, caring behavior

\section{A. Pendahuluan}

Era globalisasi dengan adanya kesepakatan WTO (World Trade Organization), yang menekankan pentingnya perdagangan antar negara secara bebas yang diibaratkan negara tanpa batas, tentu akan memberikan dampak pada dunia kesehatan khususnya pada Rumah Sakit, akan timbul persaingan dalam menarik pelanggan (pasien). Solusi yang tepat dan memenuhi harapan semua pihak adalah melalui kompetisi yang sehat yaitu meningkatkan mutu pelayanan Rumah Sakit. (Djoko Wijono, 2008:27). Rumah Sakit adalah organisasi dan manajemen dengan ciri khas, yaitu memberikan layanan medis yang dilakukan oleh tenaga medis yang professional seperti dokter, perawat, bidan, ahli gizi dan lain lain serta di dukung oleh tenaga non medis seperti tenaga administrasi, rekam medis dan tenaga teknis lainnya.(Djoko Wijono, 2008:20).

Kualitas pelayanan kesehatan dan citra suatu Rumah Sakit sangat ditentukan oleh adanya peran perawat, karena 90\% pelayanan kesehatan di Rumah Sakit diberikan oleh perawat (Suprihatin,2010:34). Dalam memberikan pelayanan keperawatan yang berkualitas dapat diterapkan dengan menggunakan caring dalam memberikan Asuhan Keperawatan kepada klien. Caring bersifat khusus dan bergantung pada hubungan antara perawat dengan klien, dimana caring memfasilitasi kemampuan perawat untuk mengenali klien sehingga perawat dapat mengetahui masalah klien dan mencari serta melaksanakan solusinya (Potter \& Perrry, 2010:159). Perilaku caring merupakan bagian terpenting dalam praktek keperawatan yang menyangkut hubungan perawat dengan klien dalam memberikan dukungan psikologis dan emosional kepada klien dan keluarga baik secara verbal dan nonverbal dalam proses pelayanan keperawatan 
sehingga dapat meningkatkan rasa aman dan keselamatan klien (Potter \& Perrry, 2010:159).

Perilaku caring dalam proses pelayanan Asuhan Keperawatan akan dapat memberikan kenyamanan, keamanan, keselamatan serta kepuasan pasien selama perawatan di Rumah Sakit. Keamanan dan keselamatan pasien merupakan hal mendasar yang perlu diperhatikan oleh tenaga medis saat memberikan pelayanan kesehatan kepada pasien. Hampir setiap tindakan medis menyimpan potensi resiko. Perilaku caring dapat terlihat pada perawat dalam memberikan asuhan keperawatan antara lain melalui mendengarkan dengan penuh perhatian, kehadiran perawat saat dibutuhkan, membina hubungan saling percaya, bertanggung jawab, kasih sayang, peduli, memberikan informasi (komunikasi), memberikan sentuhan, memberikan dorongan dan menunjukkan sikap menghargai klien. (Potter \& Perry, 2010:159).

Beberapa faktor yang mendukung terlaksananya perilaku caring dalam proses pelayanan asuhan keperawatan antara lain pengetahuan perawat tentang perilaku caring, persepsi dan sikap perawat tentang perilaku caring serta motivasi pemimpin dan perawat pelaksana dalam pelaksanaan perilaku caring. (Marseno, 2011:29). Survey yang lakukan di RSUD Solok terhadap evaluasi mutu pelayanan keperawatan terhadap kepuasan pasien diruang rawat inap RSUD Solok, berdasarkan ruangan didapatkan ruangan bedah dengan $42 \%$ baik, dan $58 \%$ kurang baik, ruangan VVIP $87 \%$ baik dan $13 \%$ kurang baik, ruangan neurologi $62 \%$ baik dan $38 \%$ kurang baik, ruangan anak $57 \%$ baik dan $43 \%$ kurang baik, ruangan kebidanan $48 \%$ baik dan $52 \%$ kurang baik, ruangan jantung $72 \%$ baik dan $28 \%$ kurang baik, ruangan paru $54 \%$ baik dan $46 \%$ kurang baik, ruangan paru $48 \%$ baik dan $52 \%$ kurang baik. (Laporan Tahunan Ruang Rekam Medik RSUD Solok) Berdasarkan data tersebut dapat dilihat bahwa di ruang rawat inap bedah RSUD Solok masih terdapat kurangnya kepuasan pasien dalam pelayanan. Menurut Burnard (2002:8) menjelaskan bahwa caring ditunjukkan melalui pengetahuan, pembelajaran dari pengalaman, sikap (kesabaran, kejujuran, Rasa percaya, kerendahan hati, harapan dan keberanian). Sedangkan menurut Potter \& Perry (2010:166) menjelaskan sikap keperawatan yang berhubungan dengan caring adalah kehadiran, sentuhan, kasih sayang, selalu mendengarkan dan memahami klien.

Pasien/klien adalah focus dari upaya asuhan keperawatan yang diberikan oleh perawat, sebagai salah satu komponen tenaga kesehatan. Dasar hubungan antara perawat dan pasien adalah hubungan yang saling menguntungkan (mutual humanity). Perawat mempunyai hak dan kewajiban untuk melaksanakan asuhan keperawatan seoptimal mungkin dengan pendekatan bio, psiko, social, spiritual sesuai dengan kebutuhan pasien. (Ismani,2010:41) Persepsi pasien menurut Sunaryo (2013:98) terhadap pelayanan keperawatan akan sangat mempengaruhi kualitas suatu rumah sakit. Dalam hal ini persepsi pasien yang akan terbangun untuk pertama kalinya adalah mengenai komunikasi dan perilaku caring yang dilakukan oleh tim medis khususnya perawat. Hal ini dikarenakan perawat memiliki waktu kontak atau berhubungan dengan pasien lebih lama dibandingkan dengan tenaga media lainnya seperti dokter, ahli labor dan gizi dan hal lainnya.

\section{B. Metodologi Penelitian}

Jenis penelitian ini adalah secara deskriptif, dilakukan terhadap sekumpulan objek yang biasanya bertujuan untuk melihat gambaran fenomena yang terjadi didalam 
suatu populasi tertentu. (Notoatmodjo, 2012:35). Dimana variabel yang akan diteliti adalah persepsi pasien terhadap pelaksanaan perilaku caring perawat di ruang rawat inap bedah RSUD Solok.

\section{Hasil dan Pembahasan}

\section{Hasil}

a. Karakterisitik Umur Responden

Tabel 1 Distribusi Frekuensi Responden Berdasarkan Kelompok Umur

Responden di Ruang Rawat Inap Bedah RSUD Solok

\begin{tabular}{|l|c|l|l|}
\hline No & Kelompok Umur & $\mathbf{f}$ & \% \\
\hline 1 & Dewasa Awal & 9 & 28,1 \\
2 & Dewasa Tengah & 14 & 43,8 \\
3 & Dewasa Akhir & 9 & 28,1 \\
\hline \multicolumn{2}{|c|}{ Jumlah } & $\mathbf{3 2}$ & \multicolumn{1}{|c|}{$\mathbf{1 0 0}$} \\
\hline \multicolumn{2}{|c|}{ Berdasarkan tabel diatas diketahui bahwa kurang dari sebagian (43,8\%) }
\end{tabular}
responden berada pada kelompok usia dewasa tengah (31-45 tahun).

\section{b. Jenis Kelamin}

Tabel 2 Distribusi Frekuensi Responden Berdasarkan Jenis Kelamin di Ruang

Rawat Inap Bedah RSUD Solok

\begin{tabular}{|c|c|c|c|}
\hline No & Kelompok Jenis Kelamin & f & $\%$ \\
\hline 1 & Laki-Laki & 19 & 59,4 \\
\hline 2 & Perempuan & 13 & 40,6 \\
\hline \multicolumn{2}{|r|}{ Jumlah } & 32 & 100 \\
\hline
\end{tabular}

Berdasarkan tabel diatas diketahui bahwa lebih dari sebagian $(59,4 \%)$ responden berjenis kelamin laki-laki.

\section{c. Pendidikan}

Tabel 3 Distribusi Frekuensi Responden Berdasarkan Tingkat Pendidikan di Ruang Rawat Inap Bedah RSUD Solok

\begin{tabular}{|l|l|l|l|}
\hline No & Pendidikan & f & \% \\
\hline 1 & Pendidikan dasar (SD- & 10 & 31,2 \\
2 & SMP) & 14 & 43,8 \\
3 & Menengah (SMA) & 8 & 25,0 \\
& Tinggi (PT) & & \\
\hline \multicolumn{2}{|c|}{ Jumlah } & $\mathbf{3 2}$ & \\
\hline
\end{tabular}

Berdasarkan tabel diatas diketahui bahwa kurang dari sebagian $(43,8 \%)$ responden berpendidikan menengah (SMA).

\section{d. Pekerjaan}

Tabel 4 Distribusi Frekuensi Responden Berdasarkan Jenis Pekerjaan di Ruang Rawat Inap Bedah RSUD Solok

\begin{tabular}{|c|c|c|c|}
\hline No & Pekerjaan & f & $\%$ \\
\hline 1 & IRT & 8 & 25,0 \\
\hline 2 & PNS & 5 & 15,6 \\
\hline 3 & Petani & 7 & 21,9 \\
\hline 4 & Wiraswasta & 12 & 37,5 \\
\hline \multicolumn{2}{|r|}{ Jumlah } & 32 & 100 \\
\hline
\end{tabular}


Berdasarkan tabel diatas diketahui bahwa kurang dari sebagian $(37,5 \%)$ responden bekerja sebagai wiraswasta.

\section{Hasil Penelitian}

Pada variabel persepsi pasien pernyataan dikategorikkan positif jika nilai $\geq$ mean (43) dan dikategorikkan negatif jika nilai < mean (43). Kecenderungan persepsi pasien terhadap pelaksanaan perilaku caring dapat dilihat pada tabel berikut:

Distribusi Frekuensi Responden Berdasarkan Persepsi Responden Terhadap

Pelaksanaan Perilaku Caring Perawat di Ruang Rawat Inap Bedah RSUD Solok

\begin{tabular}{|l|l|ll|ll|}
\hline No & Persepsi Pasien & f & \% & \\
\hline 1 & Positif & 13 & & 40,6 & \\
2 & Negatif & 19 & 59,4 & \\
\hline \multicolumn{2}{|c|}{ Jumlah } & \multicolumn{2}{|c|}{$\mathbf{3 2}$} & \multicolumn{2}{|c|}{$\mathbf{1 0 0}$} \\
\hline
\end{tabular}

Berdasarkan tabel diatas diketahui bahwa lebih dari sebagian $(59,4 \%)$ responden memiliki persepsi negatif terhadap pelaksanaan perilaku caring perawat.

\section{Pembahasan}

\section{Gambaran Persepsi Pasien Terhadap Pelaksanaan Perilaku Caring Perawat di Ruang Rawat Inap Bedah RSUD Solok Tahun 2018}

Berdasrkan hasil penelitian diketahui bahwa lebih dari sebagian $(59,4 \%)$ responden mempunyai persepsi negatif terhadap pelaksanaan perilaku caring perawat sedangkan kurang dari sebagian $(40,6 \%)$ responden mempunyai persepsi positif terhadap pelaksanaan perilaku caring perawat di ruang rawat inap bedah RSUD Solok. Hal ini sejalan dengan penelitian yang dilakukan oleh Wayan (2016) tentang gambaran persepsi pasien terhadap perilaku caring perawat di Ruang Aster RSUD Gianyar Bali. Hasil penelitian menunjukkan bahwa lebih dari sebagian $(64,8 \%)$ responden mempunyai persepsi negatif terhadap perilaku caring perawat.

Perilaku caring (caring act) adalah suatu tindakan yang dilakukan dalam memberikan dukungan kepada individu secara utuh. (Abdul,2011) tindakan dalam bentuk caring seharusnya diajarkan pada manusia sejak lahir, masa perkembangan, masa pertumbuhan sampai kala meninggal. Perilaku caring dapat dipersepsikan berbeda -beda pada setiap klien atau lingkungan tempat dimana klien mendapatkan pelayanan keperawatan. Hasil riset Kimle (2003) dalam Supriatin(2010) dikutip dari Awaliyah (2012), tentang persepsi klien terhadap perilaku caring perawat di Unit Gawat Darurat untuk kategori karatif humanistic / faithhope / sensitivity, yang dimaksud dengan perilaku caring oleh klien apabila perawat menjawab pertanyaan dengan cepat, mengetahui apa yang perawat lakukan, perawat tahu cara menginjeksi dengan benar, mengganti balutan dan lain lain, benar benar mendengarkan apabila klien berbicara, memberi obat nyeri ketika klien kesakitan, memberikan informasi kepada keluarga klien tentang perkembangan klien.

Kenyataan yang ditemukan di lapangan lebih dari sebagian $(59,4 \%)$ responden mempunyai persepsi negatif terhadap pelaksanaan perilaku caring perawat di ruang rawat inap bedah RSUD Solok hal ini dikarenakan responden masih merasa belum semua perawat dalam memberikan pelayanan terlebih dahulu memperkenalkan diri, masih belum terpenuhinya perhatian kepada responden saat pasien dirawat diruangan, masih belum merasakan lingkungan yang mendukung dan responden masih merasa adanya perawat yang belum memberikan penjelasan setiap tindakan yang akan 
dilakukan dan lebih dari sebagian $(40,6 \%)$ responden mempunyai persepsi positif terhadap pelaksanaan perilaku caring perawat diruangan rawat inap bedah hal ini dikarenakan sebagian responden sudah merasakan kehadiran perawat memberikan rasa nyaman, memberikan empati, saat dirawat diruangan.

\section{Penutup}

Berdasarkan hasil penelitian yang dilakukan terhadap 32 orang responden maka didapatkan hasil lebih dari sebagian $(59,4 \%)$ responden mempunyai persepsi negatif terhadap pelaksanaan perilaku caring perawat dan kurang dari $(40,6 \%)$ mempunyai persepsi positif terhadap pelaksanaan perilaku caring sebagian di ruang rawat inap bedah RSUD Solok. Diharapkan kepada semua perawat terutama perawat pelaksana di ruangan untuk dapat melaksanakan perilaku caring kepada semua pasien secara seoptimal karena dengan perilaku caring yang dilakukan perawat secara optimal dapat mempengaruhi bagaimana seseorang atau pasien berfikir, merasakan dan berperilaku dalam berhubungan dengan orang lain, sehingga dapat memberikan kepuasan pasien terhadap pelayanan keperawatan.

\section{Daftar Pustaka}

Abdul. 2011. Pelayanan Keperawatn di Rumah Sakit. Jakarta. Trans Info Media

Alimul, Aziz H. 2011. Metode Penelitian Keperawatan dan Teknik Analisa Data. Jakarta: Salemba Medika

Arikunto, S. 2012. Prosedur Penelitian: Suatu Pendekatan Praktek. Jakarta: Rhinneka Cipta

Asmadi. 2010. Konsep Dasar Keperawatan. Jakarta . EGC

Burnard, 2002. Konsep Keperawatan Dasar. EGC

Darmawan. 2016. Pengaruh Caring Terhadap Kepuasan Pasien di Ruang Rawat Inap Interne RSUD Babakan Lampung Selatan.

Djoko Wijono. 2010. Manajemen Pelayanan Rumah Sakit. Jakarta: Salemba Medika

Dwidiyanti, M. 2007. Caring kunci sukses Perawat Mengamalkan Ilmu; Semarang, Hasani

Efendi. 2013. Konsep Dasar Keperawatan; Jakarta : Rineka Cipta

HIPKABI. 2011. Pelatihan Caring Perawat. Jakarta. Depkes RI

Hutapea, 2014. Hubungan Perilaku Caring Perawat Dengan Tingkat Kepuasan Pasien Yang Di Rawat di Ruangan Kleas III Rumah sakit Imanuel Bandung. Jurnal Ilmu Kesehatan. Volume 8, Nomor 2, Desember 2014 ISSN 1410234

Maslina 2007. Gambaran Perilaku Caring Perawat Dalam Pemberian Asuhan Keperawatan di Instalasi Rawat Inap Rumah Sakit DR.M.Djamil Padang Skripsi : PSIK Unand tidak dipublikasikan

Morisson \& Burnard. 2012. Caring \& Comunicating.Jakarta. EGC

Muninjaya. 2012. Manajemen Mutu Pelayanan Kesehatan. Jakarta. EGC

Nila Ismani. 2010. Keperawatan Profesional. Jakarta. Rineka Cipta

Nursalam. 2008. Konsep dan Penerapan Metodologi Penelitian Ilmu Keperawatan Jakarta : Salemba Medika

Notoatmodjo. S. 2012. Metodologi Penelitian Kesehatan. Jakarta. Rineka Cipta

Potter \& Perry. 2010. Fundamental keperawatan. Jakarta. Salemba Medika 